\title{
Kyphocalanus (Copepoda: Calanoida) from deep Atlantic waters, first description of male
}

\author{
Kyphocalanus (Copepoda: Calanoida) из глубоководной Атмантики: \\ первоописание самца
}

\author{
Elena L. Markhaseva

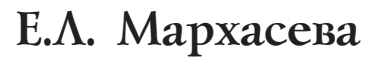

Russian Academy of Sciences, Zoological Institute; Universitetskaya nab. 1, 199034, St. Petersburg, Russia. E-mail: markhaseva@yahoo.com Зоологический институт РАН, Университетская наб. 1, Санкт-Петербург 199034, Россия.

KEY WORDS: Copepoda, Calanoida, Kyphocalanus, male, benthopelagic, Atlantic deep sea.

КЛЮЧЕВЫЕ СЛОВА: Copepoda, Calanoida, Kyphocalanus, самец, бентопелагический, глубоководная Атлантика.

ABSTRACT. A male of a rare monotypic family Kyphocalanidae is described in detail from specimen collected at abyssal depths above the sea bed in the Atlantic Ocean. Kyphocalanus male shares with female congeners the following apomorphies: maxillule praecoxal arthrite with 3 setae; maxilla endopod with 8 thick worm-like sensory setae distinctly longer than sclerotized setae of maxilla endites, and the praecoxal endites of maxilliped with a 1, 2, 0 setal formula; all are worm-like sensory elements. Proximal part of males right antennule with ancestral segments X-XI fused, P5 biramous, of simple structure; right and left protopods of nearly same length; exopods 3 -segmented.

РЕЗЮМЕ. Самец рода редкого монотипического семейства Kyphocalanidae детально описан по экземпляру из придонных абиссальных вод Атлантического океана. Самец Kyphocalanus характеризуется следующими апоморфиями, свойственными самке того же рода: прекосальный артрит максиллулы с 3 щетинками; эндоподит максиллы с 8 толстыми червеобразными сенсорными щетинками, которые заметно длиннее склеротизированных щетинок остальных эндитов максиллы и формула вооружения прекоксальных эндитов максиллипеды 1, 2, 0, причем все щетинки червеобразные. В проксимальной части антеннулы самца только анцестральные сегменты X-XI слиты, Р5 двуветвистые, простого строения; правый и левый протоподиты примерно одной длины; экзоподиты 3-segmented.

\section{Introduction}

A rare monotypic deep-water benthopelagic family Kyphocalanidae has been described only from females [Markhaseva, Schulz, 2009]. Recently a single kyphocalanid male has been recently found of the equatorial Atlantic $\left(00^{\circ} 42.7^{\prime} \mathrm{S} 05^{\circ} 31.2^{\prime} \mathrm{W}\right)$. Here this male is de- scribed for the first time and illustrated in detail; and the family diagnosis has been emended to include male characters [Markhaseva et al., 2014].

The genus Kyphocalanus includes the type species Kyphocalanus atlanticus Markhaseva et Schulz, 2009 and three species that were described but not named because of their poor condition. The representatives of the genus inhabit abyssal plains in the Atlantic Ocean at depths between 4800 and $5415 \mathrm{~m}$ and species collected at depths 3820-3744 $\mathrm{m}$ in the Antarctic Ocean. In the Atlantic Ocean the northernmost Kyphocalanus finding is $48^{\circ} 58^{\prime} \mathrm{N} 16^{\circ} 30^{\prime} \mathrm{W}$ (Kyphocalanus sp.2); south of the equator K. atlanticus and Kyphocalanus sp. 1 are found $16^{\circ} 18^{\prime} \mathrm{S} 05^{\circ} 27^{\prime} \mathrm{E}$. The southernmost occurrence of the genus, Kyphocalanus sp.3, is from Antarctic waters $\left(62^{\circ} 32^{\prime} \mathrm{S} 64^{\circ} 39^{\prime} \mathrm{W}\right)$.

Based on the male described here, females and males of Kyphocalanus appear to be very sexually dimorphic. For this reason that the taxonomic status of the male should be considered provisionary until males and females are found together.

\section{Material and methods}

A male specimen of Kyphocalanus was collected in the vicinity of the sea bed in the abyss of the equatorial Atlantic by RV Meteor during German expedition DIVA-II (Latitudinal Gradients of Deep-Sea Biodiversity in the Atlantic Ocean) in 2005 at depth of $5142 \mathrm{~m}$ by an epibenthic sledge [Brenke, 2005].

Specimens were stained by adding a solution of chlorazol black $\mathrm{E}$ dissolved in $70 \%$ ethanol / 30\% water. Oral parts and swimming legs were dissected, mounted in glycerin and figured using a camera lucida.

The following abbreviations are used in the descriptions: P1-P4, swimming legs 1-4. Free segments of the antennule are designated by Arabic numerals, ancestral segments by Roman numerals. One seta and 


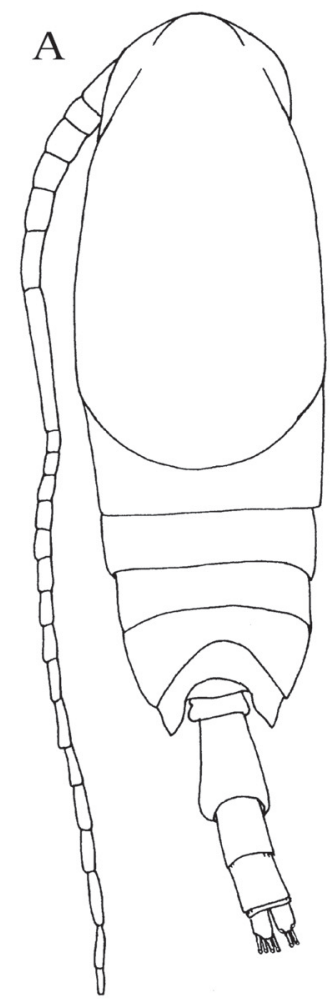

$\mathrm{B}$
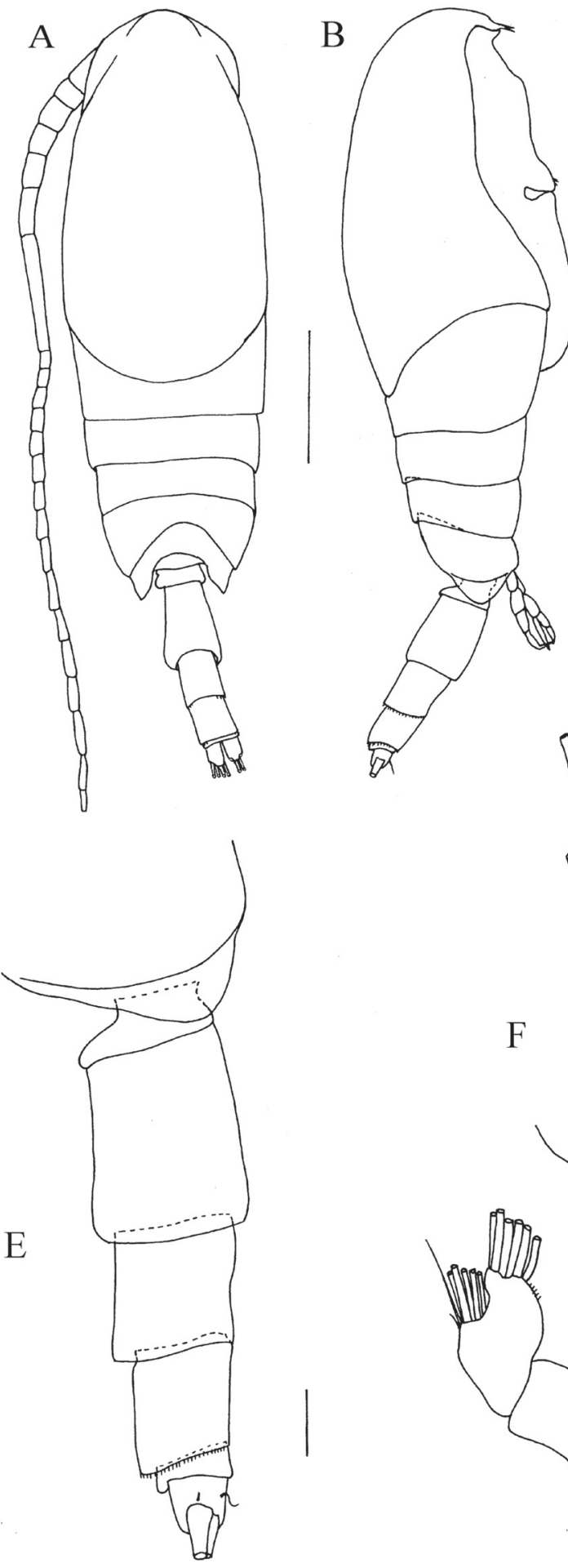

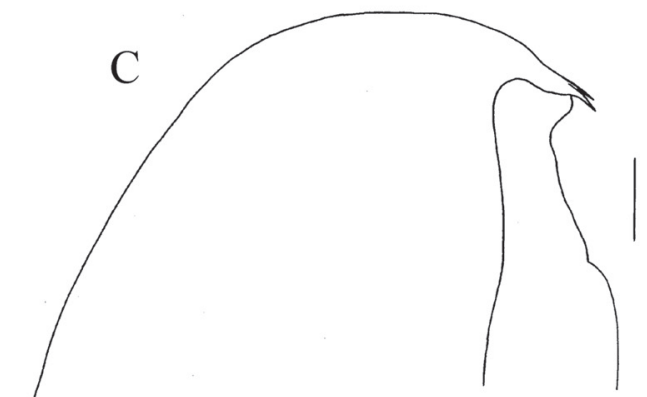

$\mathrm{D}$

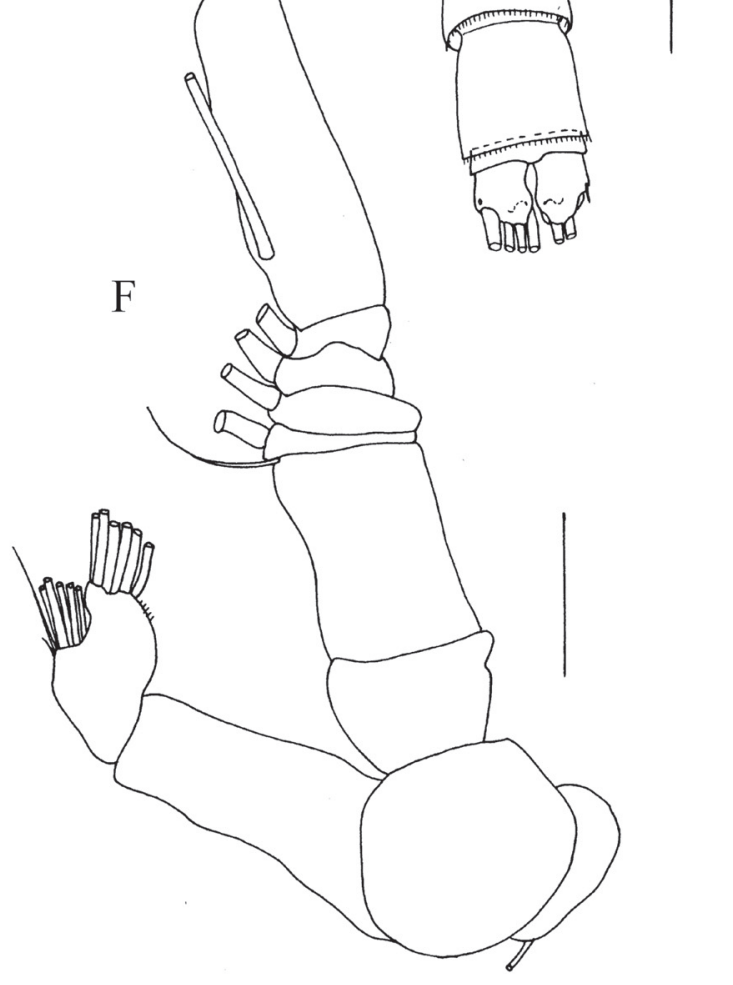

Fig. 1. Kyphocalanus sp. Male. A - habitus, dorsal view; B - habitus, lateral view; C - cephalon, lateral view; D - posterior prosome and urosome, dorsal view; $\mathrm{E}-$ posterior prosome and urosome, lateral view; $\mathrm{F}$ - antenna. Scales bars: A-B - $0.5 \mathrm{~mm}, \mathrm{C}-\mathrm{F}-$ $0.1 \mathrm{~mm}$.

Рис. 1. Kyphocalanus sp. Самец. А - общий вид со спины; В - общий вид сбоку; С - цефалон, вид сбоку; D - задняя часть просомы и уросома, вид со спины; $\mathrm{E}$ - задняя часть просомы и уросома, вид сбоку; $\mathrm{F}$-антенна. Масштаб: A-B - 0,5 мм, C-F 0,1 мм. 


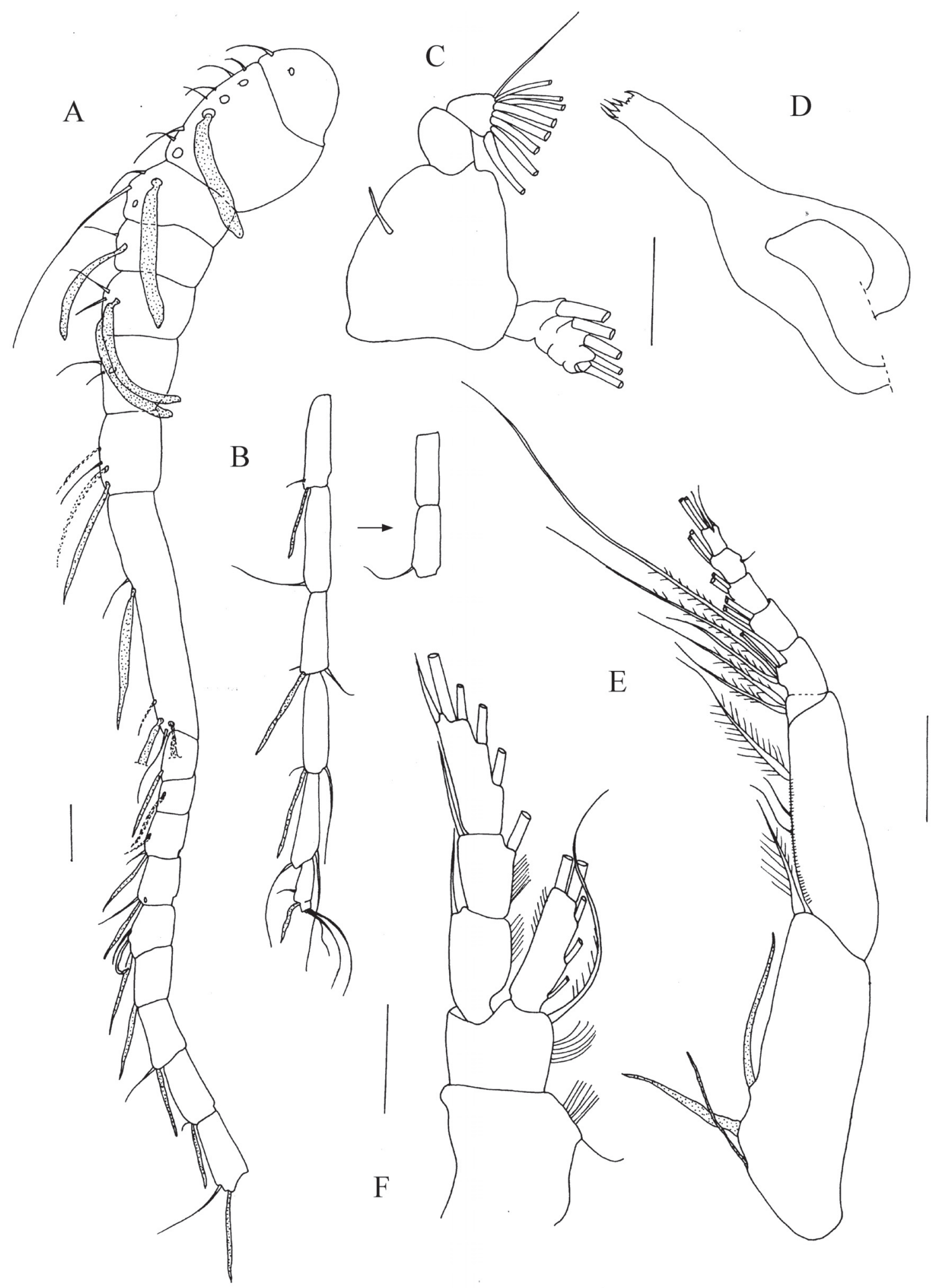

Fig. 2. Kyphocalanus sp. Male. A - right antennule, ancestral segments I-XX; B - right antennule, ancestral segments XXI-XXVIII and left antennule ancestral segments XXII-XXIII are shown by arrow; $\mathrm{C}$ - mandible, palp; D — mandible, gnathobase; E - maxilliped; F - P1. Scale bars $0.1 \mathrm{~mm}$.

Рис. 2. Kyphocalanus sp. Самец. А - правая антеннула, анцестральные сегменты I- XX; В - правая антеннула, анцестральные сегменты XXI-XXVIII и стрелкой показаны анцестральные сегменты XXII-XXIII левой антеннулы; С - мандибула, щупик; D - мандибула, гнатобаза; Е - максиллипеда; F — P1. Масштаб 0,1 мм. 


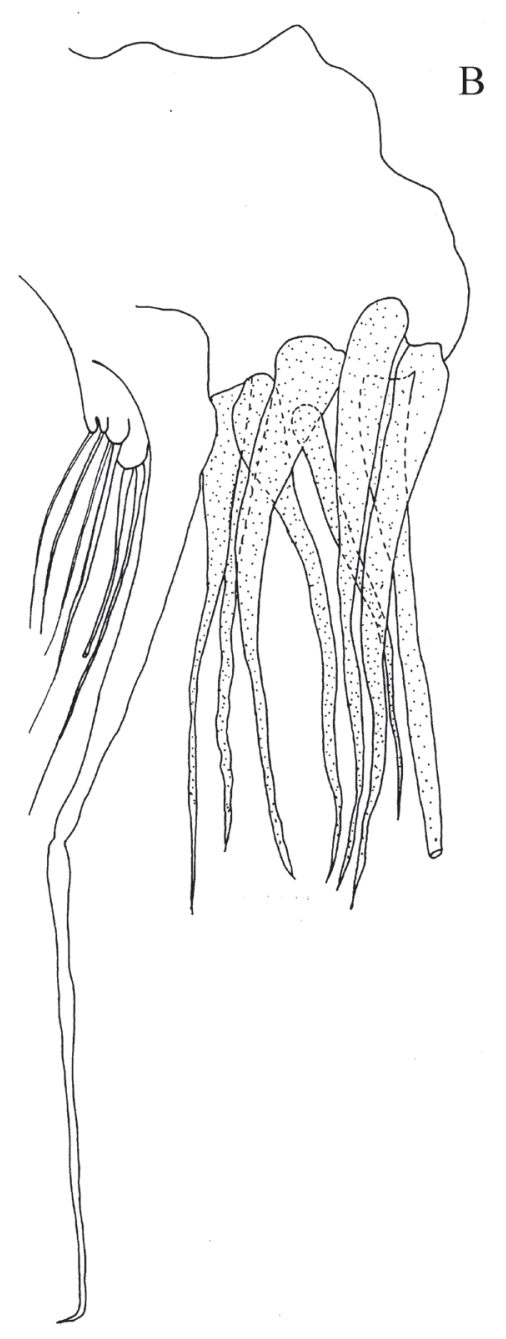

one aesthetasc on a segment of the antennule are designated: $1 \mathrm{~s}+1 \mathrm{ae}$; "1?" indicates that a setal element was broken so that its identity on the antennule could not be determined and only the scar at its former position was counted. Segments of antennule and oral parts are labeled as compiled in Markhaseva et al. [2014] after Huys \& Bosxhall [1991] for antennule and Ferrari \& Ivanenko [2008] for maxilla and syncoxa of the maxilliped.

\section{Taxonomy}

Family Kyphocalanidae Markhaseva et Schulz, 2009 Genus Kyphocalanus Markhaseva et Schulz, 2009

\section{Kyphocalanus sp.}

Figs 1-4.

MATERIAL. Atlantic Ocean, $00^{\circ} 42.7^{\prime} \mathrm{S} 05^{\circ} 31.2^{\prime} \mathrm{W}$, DIVA II expedition, 20 March 2005, above the seabed at a depth of $5140 \mathrm{~m}$ (ZIN 91119).

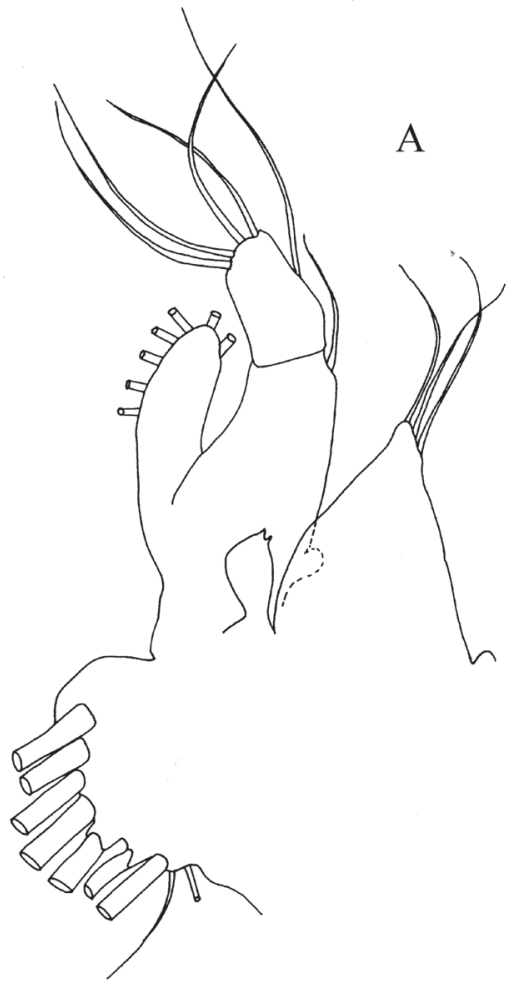

Fig. 3. Kyphocalanus sp. Male. A - maxillule; B - maxilla. Scale bars $0.1 \mathrm{~mm}$.

Рис. 3. Kyphocalanus sp. Самец. А - максиллула; В максилла. Масштаб 0,1 мм.

DESCRIPTION. Adult male, total length $2.25 \mathrm{~mm}$; prosome 3 times as long as urosome. Rostrum as two points lacking filaments (Fig. 1B-C). Cephalosome is smoothly rounded anteriorly (Fig. 1A). Cephalosome and somite 1 and somites 4 and 5 of prosome separate; posterior corners oval-triangular in dorsal view and rounded in lateral view (Fig. 1A-B, E-D). Urosome of 5 somites. Caudal rami with 4 terminal setae, 1 ventral and a dorsal seta (Fig.1D-E).

Antennule (Fig. 2A-B), slightly exceeding caudal rami, right antennule of 23, left of 24 free segments; armature of right antennule as follows: I-1s + ?, II-IV$6 \mathrm{~s}+4 \mathrm{ae}, \mathrm{V}-2 \mathrm{~s}+2 \mathrm{ae}, \mathrm{VI}-1 \mathrm{~s}+1 \mathrm{ae}, \mathrm{VII}-2 \mathrm{~s}+2 \mathrm{ae}$, VIII-2s +1 ae, IX-2s $+2 a e, X-X I-3 s+3 a e$, XII-1ae, XIII-1ae, XIV-2s + 1ae, XV-1s + 1ae, XVI-2s + 1ae (1 seta curved), XVII-1ae, XVIII-1s + 1ae, XIX-1s + 1ae, XX-1s + 1ae, XXI-1s + 1ae, XXII-XXIII-1s, XXIV-2s + 1ae, XXV-2s + 1ae, XXVI-2s + 1ae, XXVII-XXVIII-4s + 1ae.

Armature of left antennule differs in segment XVII setation as $1 \mathrm{~s}+1 \mathrm{ae}$ and segments XXII and XXIII 


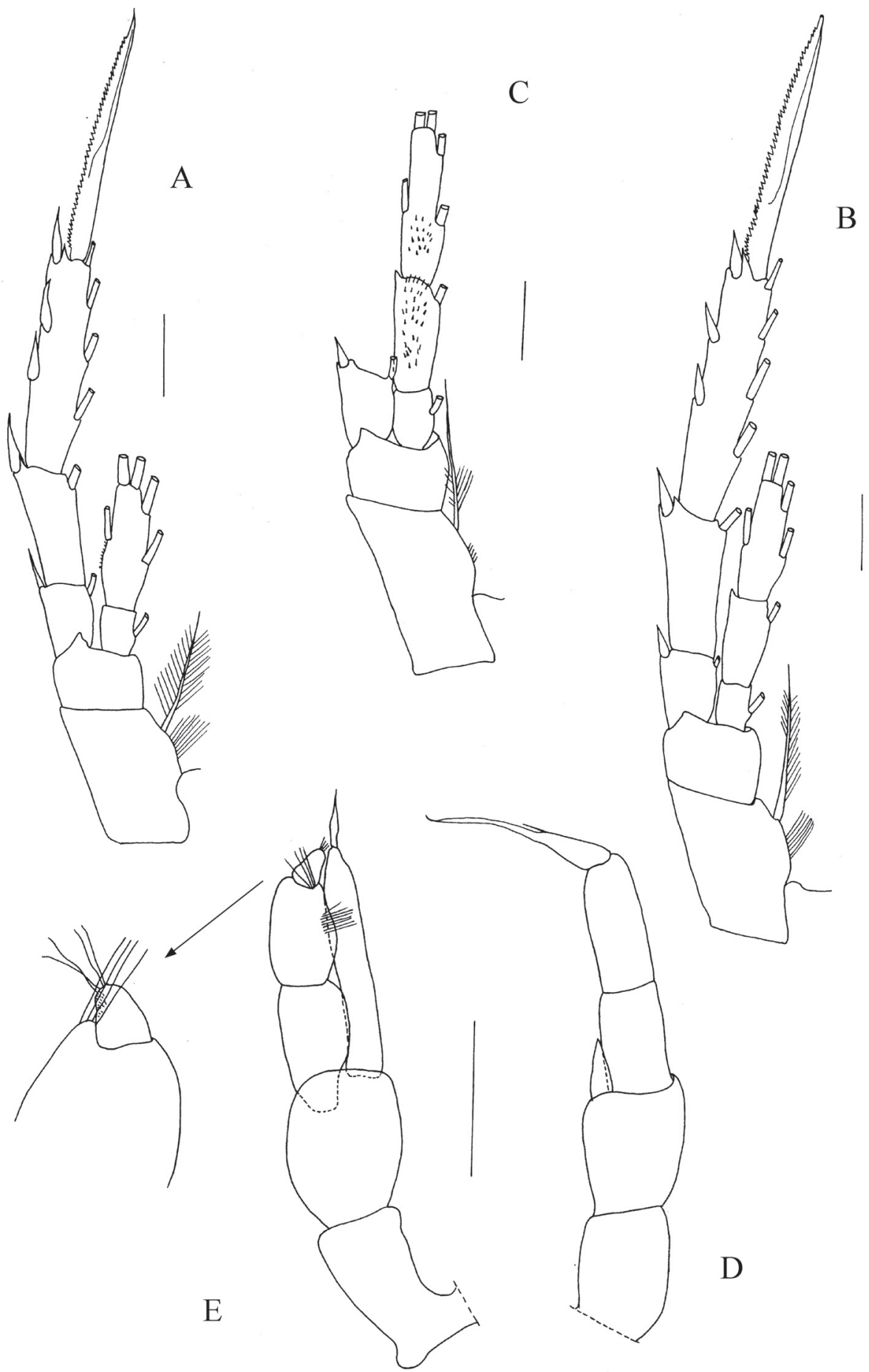

Fig. 4. Kyphocalanus sp. Male. A - P2; B - P3; C - P4, coxo-, basi-, exopod segment 1 and endopod; D - P5; E - left P5, distal part of exopod segment 2 and segment 3 . Scale bars $0.1 \mathrm{~mm}$.

Pис. 4. Kyphocalanus sp. Самец. А — P2; В - P3; C - P4, коксо-, бази-, экзоподит, сегмент 1 и эндоподит; D — P5; Е - левая нога P5, дистальная часть сегмента экзоподита 2 и сегмент экзоподита 3. Масштаб 0,1 мм.

separate, XXII without seta, XXIII-1s, and segment XXVI with $2 \mathrm{~s}+1$ ae.

Antenna (Fig. 1F), coxa with 1 seta, basis without seta; exopod of 8 free segments with $0,1,1,1,1,1,1$, and 3 setae, about 1.9 times as long as endopod; first endopodal segment without seta, second with $7+6$ setae.

Mandible (Fig. 2C-D), gnathobase long and slender, cutting edge narrow, with about 7 teeth; basis with 1 seta; exopod 5 -segmented with 1, 1, 1, 1, and 1 setae; 
endopod segment 1 without setae, segment 2 with 9 setae.

Maxillule (Fig. 3A), praecoxal endite with 3 terminal setae; coxal and proximal basal endites without setae, distal basal endite with 1 seta; endopod with 5 setae; exopod with 7 setae; coxal epipodite with $9+2$ setae.

Maxilla (Fig. 3B), praecoxal endite (the proximal endite) with 1 seta; proximal coxal endite (adjacent to the proximal endite) with 1 setae; basal endites (the two following endites) with 2 setae each; enditic-like lobe of proximal endopodal segment with 1 spine; endopod with 8 long and thick worm-like sensory setae.

Maxilliped (Fig. 2E), syncoxa with 1 seta on proximal praecoxal endite, 2 setae on middle praecoxal endite and without setae on distal praecoxal endite, all setae worm-like; coxal endite with 1 seta. Basis with 3 proximal and 2 distal setae. Endopod 5-segmented with 4, 2, 2, 2+1, and 4 setae.

Swimming legs. P1 (Fig. 2F), basis with medial distal seta slightly curved, with setules; endopod 1segmented without lateral lobe, outer margin without a slight undulation in a proximal half of segment; exopod segments 1 to 3 with 1 lateral spine each, spine of segment 3 the shortest. P2-P4 (Fig. 4A-C), coxa with 1 seta; basis without seta; endopod 2-segmented in P2, 3-segmented in P3-P4; exopods 3-segmented (exopodal segments 2 and 3 of P4 broken). Posterior surface of P4 endopodal segments 2 and 3 spinulate.

P5 (Fig. 4D-E), biramous, of simple structure; right and left protopods of nearly same length; endopods 1segmented, right short, left reaching to terminal part of exopod and supplied by terminal spine; exopods 3segmented, segment 3 of right exopod is narrowed distally and is supplied by a small spine in about middle, segment 3 of left exopod is small, rounded distally and supplied by setules.

REMARKS. Male and female of Kyphocalanus demonstrate significant sexual dimorphism in body shape and antennule armament. Male cephalon is anteriorly smoothly rounded, while in female it is pronounced and strongly bent. Male antennule armament is as following: 1) segment I with 1 seta (vs $2 \mathrm{~s}$ in female); 2) segments II-IV with 4 aesthetascs (vs single aesthetasc in female); 3) segments X-XI with 3s + 3ae (vs 4s + 1ae in female); 4) segments VI and XX with $1 \mathrm{~s}+1 \mathrm{ae}$ (vs 2s in female); 5) each of segments XII-XIII and XVII with 1ae (vs 1s in female), and 6) in male compared to female, one more aesthetasc present on ancestral segments V, VII-IX, XV, XVIII-XIX, XXIV-XXVI.

The male of Kyphocalanus described here shares most diagnostic characters of Kyphocalanidae [Markhaseva, Schulz, 2009] with females and differ from females only in a few details. These details are, more probably, sexually dimorphic, e.g., 1) antenna second endopod segment of the male with $7+6$ setae (vs $4+6$ setae in female);2) mandible basis with 1 seta of common shape (vs basis with 2 setae, of them proximal seta with basal part shaft-like in female); 3) maxillule coxal endite without setae (vs with 2 setae in female); 4) maxilla praecoxal endite with 1 seta and proximal coxal endite with 1 setae each (vs with 2 setae each in female), and 5) maxilliped syncoxa with the middle praecoxal endite worm-like sensory setae moderately long and thick (vs 2 very long and thick worm-like setae on middle lobe, extending to distal part of endopod in females).

ACKNOWLEDGEMENTS. Author thanks Prof. Pedro Martinez Arbizu for providing the sorted copepod fraction of the DIVA-II expedition. Many thanks to Frank Ferrari for valuable comments and improving English of the early draft of this manuscript The research of E.L. Markhaseva at the Deutsches Zentrum fuer Marine Biodiversitaetsforschung Senckenberg, Biozentrum Grindel and Zoologisches Museum Hamburg was supported by Senckenberg and by 12-0400071-a grant of the Russian Foundation for Basic Research.

\section{References}

Brenke N. 2005. An epibenthic sledge for operations on marine soft bottom and bedrock // Marine Technology Society Journal. Vol.39. P.10-19.

Ferrari F.D., Ivanenko K. 2008. The identity of protopodal segments and the ramus of maxilla 2 of copepods (Copepoda) // Crustaceana. Vol. 81. P.823-835.

Huys R., Boxshall G.A. 1991. Copepod Evolution. London: The Ray Society. 468 p.

Markhaseva E.L., Laakmann S., Renz J. 2014. An interim synopsis of the Bradfordian families with a description of Thoxancalanus spinatus (Copepoda: Calanoida), a new diaixid genus and species from the deep Atlantic Ocean. Springer // Marine Biodiversity. Vol.44. P.63-88.

Markhaseva E.L., Schulz K. 2009. A new family and genus of calanoid copepods (Crustacea) from the abyss of the Atlantic Ocean // Zootaxa. Vol.2304. P.21-40.

Responsible editors S.I. Golovatch, K.G. Mikhailov 